\title{
今月の症例 $气$
}

\section{リツキシマブが有効であった 多発血管炎性肉芽腫症に伴う 肥厚性硬膜炎の1例}

\begin{tabular}{|c|c|c|c|}
\hline 野 れな1） & & & $\begin{array}{c}\text { 藤田 耕太朗 2) } \\
\text { 中 }\end{array}$ \\
\hline & & 小山 雄太 ${ }^{4)}$ & 中山 隆弘2) \\
\hline
\end{tabular}

65 歳, 男性. 13年前に肥厚性硬膜炎と慢性中耳炎を発症し, プレドニゾロン単剂で治療された. 2 年後，半月 体形成性糸球体腎炎を発症し，多発血管炎性肉芽腫症と診断された. シクロホスファミドを併用した寛解導入療 法が行われた. しかし，寛解維持療法は難渋し，肥厚性硬膜炎が再発した. これに対して，リッキシマブによる 寛解導入療法と維持療法を行ったところ，長期間寛解を維持することができた.

〔日内会誌 109：1124～1129，2020]

ポイント・多発血管炎性肉芽腫症の脳神経病変としては，末梢神経病変が多く，中枢神経病変は稀で ある.

・肥厚性硬膜炎は慢性頭痛の原因になり，進行すると脳神経麻痺を来たすこともある.

・肥厚性硬膜炎の診断には，造影MRIが有用である。

・ANCA関連血管炎の寛解導入療法は，グルココルチコイド+シクロホスファミドが推奨さ れ，代替薬としてリツキシマブも使用できる.

Key words 多発血管炎性肉芽腫症 (GPA)，肥厚性硬膜炎，リツキシマブ

\section{はじめに}

多発血管炎性肉芽腫症（granulomatosis with polyangiitis：GPA）は, 抗好中球細胞質抗体 (anti-neutrophil cytoplasmic antibody: ANCA) が 陽性となる小型・中型血管の壊死性血管炎で, 上気道や肺の壊死性肉芽腫性病変, 腎臓の半月 体形成性糸球体腎炎等を特徵とする ${ }^{1)}$.

GPAの神経系の病変としては, 多発性単神経 炎やポリニューロパチーが 15～50\% と高頻度
にみられる。一方，中枢神経病変は 5〜 15\%と 比較的稀であり ${ }^{2)}$, 脳神経障害, 下垂体機能障 害ならびに頭蓋内や脊椎内の肥厚性硬膜炎等が ある ${ }^{3)}$. 肥厚性硬膜炎は他の疾患でも出現する ため, 原因疾患の鑑別診断が必要である. 進行 すると脳神経障害を引き起こす可能性があり， 適切な治療を要する.

今回, GPAに合併した再発性肥厚性硬膜炎に 対し，リツキシマブを用いて寛解導入療法及び 寛解維持療法を行い，良好な治療反応がみられ 
た症例を経験したため，提示する.

\section{症例}

患者：65歳, 男性.

主訴：右上下肢の不全麻痺, 異常知覚.

現病歴: X-13年, 鼻閉と難聴が出現し, 耳 鼻咽喉科で中耳炎として保存的加療を受けてい た。同時期に慢性頭痛もみられるようになった が，原因が不明のまま 1 力月程経過した後に軽 度の意識障害が出現した。頭部造影MRI（magnetic resonance imaging）を施行したところ，肥 厚性硬膜炎と診断された。治療として, 高用量 のプレドニゾロンを静注したところ, 著効した

ーーロメモ 肥厚性硬膜炎の診断においては，単純 MRIでは見逃す危険があり，造影MRIを施 行した方がよい。

その後, プレドニゾロン単剤で治療が行われ ていたが，慢性頭痛が改善せず，20 mg以下に 減量することが困難であった。 X-11年，尿蛋 白と尿潜血を認める腎機能の低下を認め，腎生 検を施行した. 生検の結果, pauci-immune型半 月体形成性糸球体腎炎が確認された。厚生労働 省のGPAの診断基準のうち, 主要所見の中耳炎 と糸球体腎炎があり, 腎臟の組織学的検査で免 疫グロブリン沈着を伴わない壊死性半月体形成 腎炎の所見が確認され, PR3 (proteinase 3) が $157 \mathrm{U} / \mathrm{ml}$ と上昇していたことから，GPAと診断 した.

プレドニゾロンと経ロシクロホスファミドで 腎炎は寬解した。 シクロホスファミドは有効で あったが, 累積投与量が 10 gに達し, 発癌リス クが危惧された．免疫抑制薬をアザチオプリン やメトトレキサートに変更したが, 慢性頭痛や 三叉神経痛が再発し，無効であった。その後, 複視と眼窩腫脹が出現し, MRIを行ったところ, 眼窩に腫瘤性病変が出現していた。この病変は プレドニゾロンを増量し消失した。その後はシ クロスポリンを併用してプレドニゾロンは
$10 \mathrm{mg}$ 程度まで減量することができていた。

$X$ 年 7 月から眼の奥に強い痛みを感じるよう になり, プレドニゾロンを増量した. 一旦は改 善したものの, 減量を試みたところ, 頭痛の再 燃と共に右上下肢に不全麻痺と異常知覚が出現 し，脳血管障害を疑われ，救急外来を受診した。

既往歴：高脂血症, 陳旧性脳梗塞, 発作性心 房細動, 前立腺肥大症.

内服薬：プレドニゾロン $20 \mathrm{mg}$, アレンドロ ン酸 $35 \mathrm{mg}$, エルデカルシトール $0.75 \mu \mathrm{g}$, スル ファメトキサゾール $400 \mathrm{mg}$, トリメトプリル $80 \mathrm{mg}$, シクロスポリン $150 \mathrm{mg}$, アトルバスタ チン $5 \mathrm{mg}$, アスピリン $100 \mathrm{mg}$, ジゴキシン $0.25 \mathrm{mg}$, タムスロシン $0.2 \mathrm{mg}$.

身体所見：意識清明。体温 $36.6^{\circ} \mathrm{C}$. 脈拍 68/ 分, 整. 血圧 $162 / 97 \mathrm{mmHg}, \mathrm{SpO}_{2} 99 \%$. 対光 反射正常, 項部硬直なし, 顔面神経麻痺はなし. 上肢Barré徴候と下肢Mingazzini試験で右側が陽 性であり, 同部位に触覚低下と異常知覚を認め る. 右足関節の背屈能低下を認める.

\section{一ロXモ 右腓骨神経の運動神経伝導速度が低下} しており，右足関節の背屈障害は腓骨神 経の単神経炎によるものと考えた。

血液検査所見：赤血球 403 万 $/ \mu 1, \mathrm{Hb} 10.5 \mathrm{~g} /$ $\mathrm{dl}$, 白血球8,760/ $\mu 1$, 血小板 18.4 万/ $\mu 1 . \mathrm{TP} 6.6 \mathrm{~g} /$ dl, Alb 4 g/dl, BUN 23.4 mg/dl, Cr 0.9 mg/dl, 総ビリルビン $0.7 \mathrm{mg} / \mathrm{dl}$, AST $11 \mathrm{IU} / 1$, ALT $11 \mathrm{IU} / 1$, LD 172 IU/l, ALP $160 \mathrm{IU} / 1$, Na $139 \mathrm{mEq} / 1$, K $3.9 \mathrm{mEq} / 1$, Cl $102 \mathrm{mEq} / 1$, Ca $8.9 \mathrm{mg} / \mathrm{dl}$, CK $30 \mathrm{IU} / 1, \mathrm{CRP} 1.08 \mathrm{mg} / \mathrm{dl}$, 抗核 抗体 $<40$ 倍, 抗SS-A/Ro抗体 陰性, C3 $159 \mathrm{mg} /$ dl, C4 30 mg/dl, PR3-ANCA $26.1 \mathrm{U} / \mathrm{ml}$, MPOANCA $<1.0 \mathrm{U} / \mathrm{ml}$, 可溶性IL（interleukin)-2レセ プター315 U/ml. 髄液所見 : 細胞数 $8 / \mu \mathrm{l}$, 単核 球 : 多核球 $=6: 2$ (個), 総蛋白 $90.6 \mathrm{mg} / \mathrm{dl}$, Glu $56 \mathrm{mg} / \mathrm{dl}$. 頭部画像所見 : 単純CT (computed tomography）とMRIでは異常所見を確認できな かったが，改めて造影MRIを撮影し直したとこ ろ, 造影効果を伴った左頭頂部硬膜の肥厚及び 

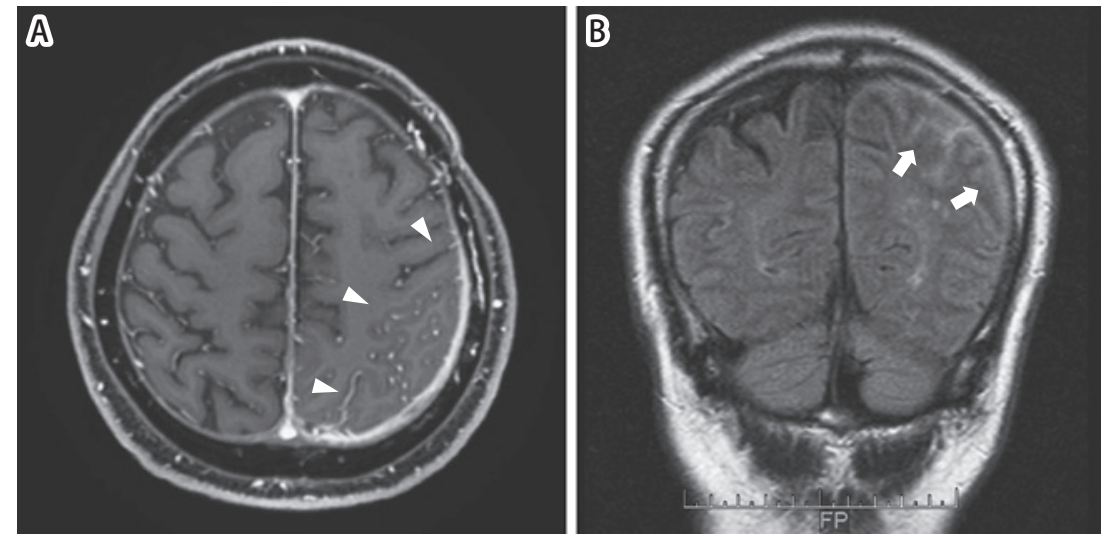

図 1 頭部MRI

$\mathrm{A}$ ：横断面 (Gd造影T1強調画像)：Gdによる造影効果を伴った限局性の硬膜肥厚と 脳溝の消失脳溝が消失している (白矢頭)。

B : 冠状断面 (FLAIR像)：左頭頂に軽度の高信号がみられる（白矢印）.

FLAIR : fluid-attenuated inversion recovery

脳溝の消失が確認され，炎症は一部脳実質まで 及んでいた（図1)。

一ロXモ左頭頂部に起きた肥厚性硬膜炎の炎症 が脳実質に及び，右上下肢麻痺が生じた と考えられた.

\section{臨床経過}

GPAによる肥厚性硬膜炎の再発と考え, メチ ルプレドニゾロン $1,000 \mathrm{mg}$ を 3 日間点滴し，プ レドニゾロン $60 \mathrm{mg} /$ 日で後療法を行った。第 6 病日に再検した頭部MRIでは硬膜肥厚と脳浮腫 所見の改善を認めていた. 第 11 病日からリッキ シマブ $375 \mathrm{mg} / \mathrm{m}^{2}$ の投与を開始した. その頃に は不全麻痺と異常知覚も改善した。その後,リ ツキシマブを週 1 回の間隔で 4 回投与し，その 間にプレドニゾロンを $25 \mathrm{mg}$ まで減量して退院

\section{した（図2).}

退院後も再発はみられず, 5力月でPR3-ANCA は陰性化した.6力月毎にリツキシマブ375 mg/ $\mathrm{m}^{2}$ を投与したところ， 2 年後には，プレドニゾ ロンの投与を終了することができた（図2）。そ れから 2 年以上, リッキシマブによる寛解維持
療法を続けているが，長期間寛解を維持できて いる.

\section{考察}

GPAにおいて，神経症状を呈することはよく 知られているが，その多くは末梢神経障害であ り, 中枢神経障害は5～15\%と比較的稀である. しかし, 肥厚性硬膜炎の画像所見は $36 \%$ にう れたという報告 ${ }^{4)}$ もることから, 軽微な病変 は見逃されている可能性がある

GPAの肥厚性硬膜炎は, 病理学的には, 脳や 脊髄の髄膜に壊死性肉芽腫性病変ができること が原因とされる。頭痛や背部痛を発症し，時に 脳神経障害やさまざまな中枢神経症状を呈す る5)。肥厚性硬膜炎は, 目, 耳ならびに上気道 に限局するタイプのGPAに合併する頻度が高い と報告されている5). 今回の症例は中耳炎を呈 していたが，耳鼻咽喉科領域では，初期症状と しての中耳炎を見逃さないため, 最近, ANCA関 連血管炎性中耳炎 (otitis media with ANCA-associated vasculitis： OMAAV）として慎重に扱われ るようになっている6). 


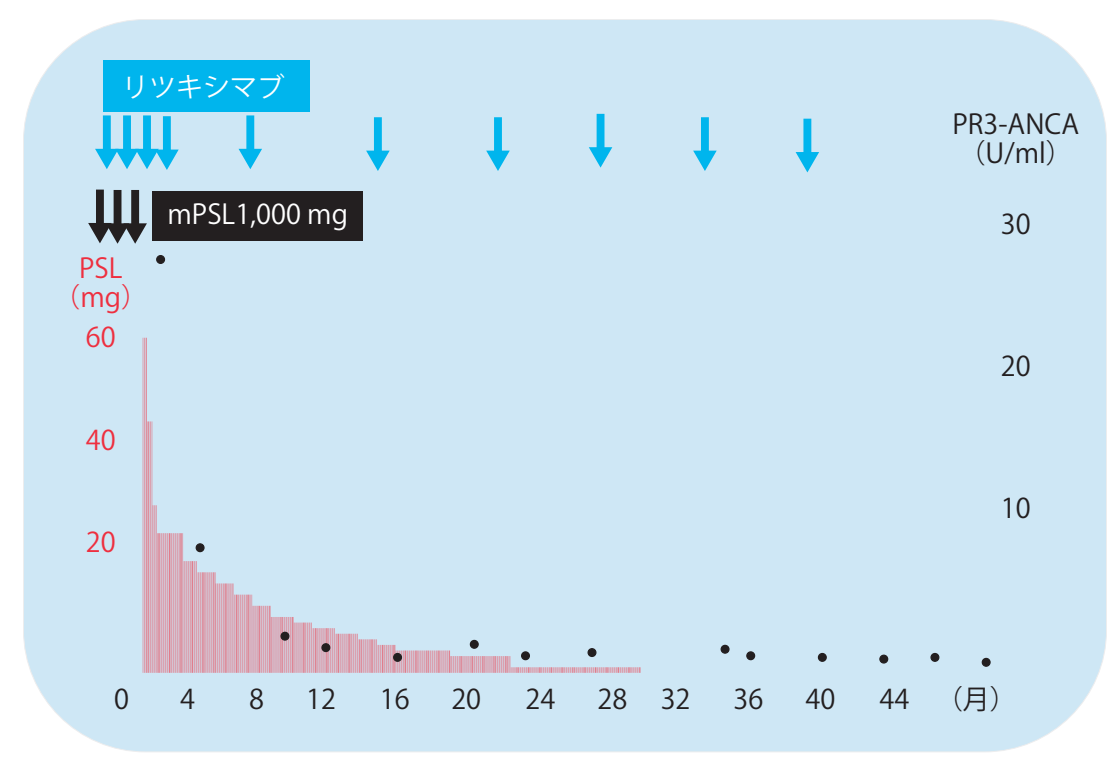

図 2 治療経過

黒点はPR3-ANCAの測定値を示す.

mPSL : methylprednisolone

肥厚性硬膜炎の診断には, 造影MRI T1 強調像 が有用であり，造影効果を伴う硬膜肥厚像とし て捉えることができる7). 本症例のように，脳 表まで病変が及ぶこともある，ただし，結核や 真菌等の感染症, サルコイドーシス, IgG4 （immunoglobulin G4）関連疾患，腫瘍でも同様 の病変が出るため, 全身検索や髄液検査を含め た慎重な鑑別が必要となる. 稀にGPAの初発症 状として肥厚性硬膜炎が出現することもあり, その場合は, 髄膜生検が必要になることもある ${ }^{5)}$.

GPAを含めたANCA関連血管炎（ANCA-associated vasculitis：AAV）の治療は, 寛解導入療法 としてのグルココルチコイドとシクロホスファ ミドの併用療法, その後は免疫抑制薬をアザチ オプリンに変更して寛解維持療法を行うことが 標準治療とされている8). 抗CD20モノクローナ ル抗体であるリツキシマブも寛解導入療法でシ クロホスファミドに対して非劣勢であることが 示され，特にAAV再発例においては，再発率が 低下することを期待できる ${ }^{9)}$.ただし，中枢神
経病変に対する効果は未だ明らかではなく，有 効性を報告した症例報告においても, 再発率が 高い可能性が示唆されている ${ }^{4)}$. 一方, 寛解維 持療法に関しては, アザチオプリンの代わりに リツキシマブを用いることで長期の再発率も下 げられることがランダム化比較試験で示されて いる10).

一ロメモ リツキシマブは, ANCA関連血管炎の治 療において，寛解導入療法及び寛解維持 療法のいずれにおいても有効であるが， 第一選択薬ではない。

本症例は, シクロホスファミドによる寛解導 入療法後も再発を繰り返していたため, 寛解導 入療法及び寛解維持療法としてリツキシマブを 継続的に用いたところ，良好な経過をたどっ た.しかしながら，長期に投与した場合の安全 性等については不明な点が多いため, 注意深い 経過観察が必要である。 
最終診断

\section{GPAに伴う肥厚性硬膜炎}

\section{おわりに}

GPAに伴う肥厚性硬膜炎の寬解導入療法及び
寬解維持療法に, リツキシマブが有効であった 1 例を経験した。 肥厚性硬膜炎は比較的稀な病 態であるが，時に脳神経麻痺等を生じるため, 注意が必要である.

著者のCOI（conflicts of interest）開示：本論文発表内容 に関連して特に申告なし

\section{文献}

1) Lamprecht P, Gross WL : A brief history of Wegener's granulomatosis : on limited, localized, and generalized forms of the disease: comment on the article by the Wegener's Granulomatosis Etanercept Trial Research Group. Arthritis Rheum 50 : 334-336, 2004.

2) Wludarczyk A, Szczeklik W : Neurological manifestations in ANCA-associated vasculitis - assessment and treatment. Expert Rev Neurother $16:$ 861-863, 2016.

3) De Luna $G$, et al : Central nervous system involvement of granulomatosis with polyangiitis : clinical-radiological presentation distinguishes different outcomes. Rheumatology (Oxford) $54:$ 424-432, 2015.

4) Choi HA, et al : Characteristics of hypertrophic pachymeningitis in patients with granulomatosis with polyangiitis. J Neurol $264: 724-732,2017$.

5) Di Comite G, et al : Meningeal involvement in Wegener's granulomatosis is associated with localized disease. Clin Exp Rheumatol 24 (2 Suppl 41) : S60-64, 2006.

6) Harabuchi $Y$, et al : Clinical features and treatment outcomes of otitis media with antineutrophil cytoplasmic antibody (ANCA)-associated vasculitis (OMAAV) : a retrospective analysis of 235 patients from a nationwide survey in Japan. Mod Rheumatol $27: 87-94,2017$.

7）河内 泉，西澤正豊：肥厚性硬膜炎. 日内会誌 99：1821-1829, 2010.

8）厚生労働科学研究費補助金 難治性疾患等政策研究事業（難治性疾患政策研究事業）難治性血管炎に関する調査研究 班，他：ANCA関連血管炎診療ガイドライン 2017. 初版，診断と治療社，東京，2017, 15-33.

9) Stone JH, et al : Rituximab versus cyclophosphamide for ANCA-associated vasculitis. N Engl J Med 363 : 221232, 2010.

10) Guillevin L, et al : Rituximab versus azathioprine for maintenance in ANCA-associated vasculitis. N Engl J Med $371: 1771-1780,2014$. 


\section{日本海総合病院 腎臓膠原病内科}

当院は, 山形県のなかでも日本海沿岸地域で ある庄内地方にあります。古くは, 日本海海運 で活躍した北前船の寄港地として栄えた場所 で，NHKの連続テレビ小説で「おしん」が幼少 期に奉公した場所でもあります。今も米作りが 盛んで, 庄内地方版図柄入りナンバープレート には稲穂が描かれていますし，JR東日本新潟駅 との間を運行している特急列車の名前は「いな ほ」です。

\section{【病院紹介】}

当院は, 2008年に旧山形県立日本海病院と旧 市立酒田病院が統合再編して地方独立行政法人 化したユニークな病院です。「ちょうかいネッ ト」という医療情報共有ネットワークによっ て, 地域の病院, 診療所, 介護施設ならびに薬 局等から当院の診療録を閲覧することができま す.また, 2018年からは地区医師会, 地域の病 院，診療所ならびに介護施設等が「日本海ヘル スケアネット」という 1 つの地域医療連携推進 法人を形成し, 医療の効率化が試みられていま す。そのため，急性期の医療を提供するという 当院の立場はより明確になってきています。

\section{【診療内容】}

5 名のスタッフ（山形大学第一内科からの2名 を含む）で，腎疾患とリウマチ・膠原病の専門 診療と総合内科診療を行います。前述のよう に, 地域の中核病院としての機能を担うため, 庄内という辺境の地にありながら，いつでも標
準医療を提供できるように努めています.

\section{【入院診療】}

約 20 床を担当し, 腎疾患や膠原病の治療導 入, 合併症治療, 腎生検（年間 40 症例）ならび に総合内科としての (準) 緊急入院を診療して います。

\section{【外来診療】}

腎疾患とリウマチ・膠原病疾患が半々であ り，定期的にカンファレンスを行い，診断や治 療方針をお互いに確認し合っています。

\section{ホームページ}

http://www.nihonkai-hos.jp/hospital/jinzounaika. html

文責：日本海総合病院腎藏膠原病内科 内科部長（兼）人工透析室副室長 中山 隆弘

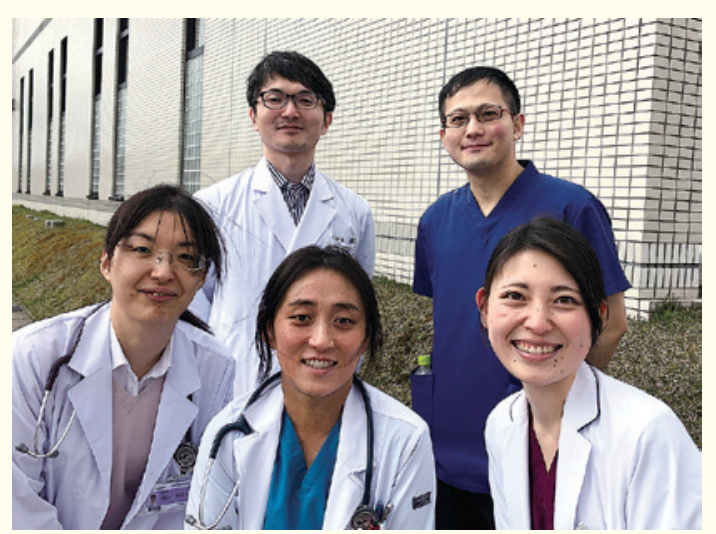

